\title{
Perceived Usefulness, Perceived Ease of Use, and Social Influence: Intention to Use e-Wallet
}

\author{
Femmy Effendy ${ }^{1, *}$ Ratih Hurriyati ${ }^{2,}$ Heny Hendrayati ${ }^{3}$
}

\author{
${ }^{1}$ Universitas Pendidikan Indonesia \\ ${ }^{2}$ Universitas Pendidikan Indonesia \\ ${ }^{3}$ Universitas Pendidikan Indonesia \\ ${ }^{*}$ Corresponding author. Email: femmy.effendy@upi.edu
}

\begin{abstract}
Research on the acceptance of the use of information technology often uses the Technology Acceptance Model (TAM) and the Unified Theories of Acceptance and Use of Technology (UTAUT) model, which provide an excellent theoretical basis for understanding consumer intentions to use non-cash payment transactions. Non-cash payment methods used in this study were e-wallets such as OVO, Go-Pay, T-cash, and others. This study combined these two theoretical models mentioned above and aimed at determining the effect of perceived usefulness, perceived ease of use, and social influence on the intention to use e-wallets. The survey was conducted involving STMIK Rosma Karawang students in the information system study program (2019-2020) with a population of 160 students. Samples taken by purposive sampling obtained 137 respondents. The analysis technique used was multiple linear regression using SPSS V23. The results showed a positive and significant influence on perceived usefulness and perceived ease of use on intention. However, it turned out that social influence did not have a significant effect. This study's results serve as a guideline or reference for companies developing e-wallet applications in the future. The company expects to make a more comfortable and easier to use applications and always be consistent in providing users.
\end{abstract}

Keywords: e-wallets, perceived usefulness, perceived ease of use, social influence.

\section{INTRODUCTION}

Behavior intention is still one of the topics that are widely studied in various disciplines. Behavioral intentions were first defined by $[1,2]$ as consumers' desires to behave in certain ways to own, dispose of, and use products or services. Behavior intention that will lead to behavioral use becomes an exciting and essential thing to study from a variety of different research subjects. Meanwhile according [3], intention to use is a strong desire to achieve what someone wants and will not allow anything that can interfere with the achievement of these goals.

Digital payments in the form of electronic wallets or e-wallets increasingly becomes interesting to study, by looking at the facts on the ground that electronic wallet users in Indonesia such as OVO, Go-Pay, T-cash, and others are growing rapidly from year to year. Based on Bank Indonesian (BI) data (2020), growth in digital payment transactions had an increase by $94.7 \%$ from 2014. Electronic wallet or e-wallet is a type of electronic payment account where users can save money for every transaction in the future [4].

Besides, the emergence of cashless society is a designation that refers to people who do not use physical money in transactions, but through digital financial information transfer [5], [6] In daily transactions, people do not use real money, but digital money.

Reference [7] created the Technology Acceptance Model (TAM) theory with an emphasis on perceived ease of use and perceived usefulness that have a relationship to predict attitudes in using an information technology system. TAM is one type of theory that uses a behavioral theory approach that is widely used to study the process of information technology adoption. Usability perception is a system with high perceived usefulness that will make users believe in the relationship between use and positive performance [8]. In other way [7] stated that perceived ease of use is defined as the extent to which a person believes that using technology will be free of effort. Perceived ease 
of use is based on the extent to which prospective users expect the new system to be used free from difficulties [9]

UTAUT is one of the latest technology acceptance models developed by [10]. UTAUT combines the successful features of eight leading technology acceptance theories into one theory. The four main constructs that play an important role as direct determinants of behavioral intention and use behavior are performance expectancy, effort expectancy, social influence, and facilitating conditions. In addition, there are also four moderators namely gender, age, voluntariness, and experience that are positioned to moderate the impact of the four main constructs. Social influence is defined as the extent to which a person feels that someone else is trusted suggesting that he should use a new system. [11]. A research conducted by [12] revealed that there was a positive relationship between social influence and behavioral intention. Thus, this study aims to analyze the effect of perceived usefulness, perceived ease of use, and social influence on intention to use e-wallets.

\section{METHODS}

This type of research is explanatory research. The variables used were perceived usefulness, perceived ease of use, and social influence on intention to use an e-wallet. This study was conducted at STMIK ROSMA Karawang involving students of Information Systems Study Program. The sample used was 137 respondents from total population of 160 students. Sampling method used was non-probability sampling with purposive sampling. The research instrument in the form of a questionnaire used a semantic differential scale 1-5. The tool used to analyze data was the IBM SPSS 23 with the stages of the analysis method through the validity test of the data and reliability test, the Classical assumption test with the Normality test or Kolmogorov-Smirnov nonparametric statistical test (KS), Multicollinearity test, heteroskedasticity test, hypotheses test with F-test and the partial relationship test with the t-test.

\subsection{Research Hypothesis}

Based on the research model in Figure 1, hypotheses in this study are:

- H1: Perceived Usefulness has a positive and significant effect on Intention to Use e-wallet applications.

- H2: Perceived Ease of Use has a positive and significant effect on Intention to Use e-wallet applications.

- H3: Social Influence has a positive and significant effect on Intention to Use e-wallet applications.

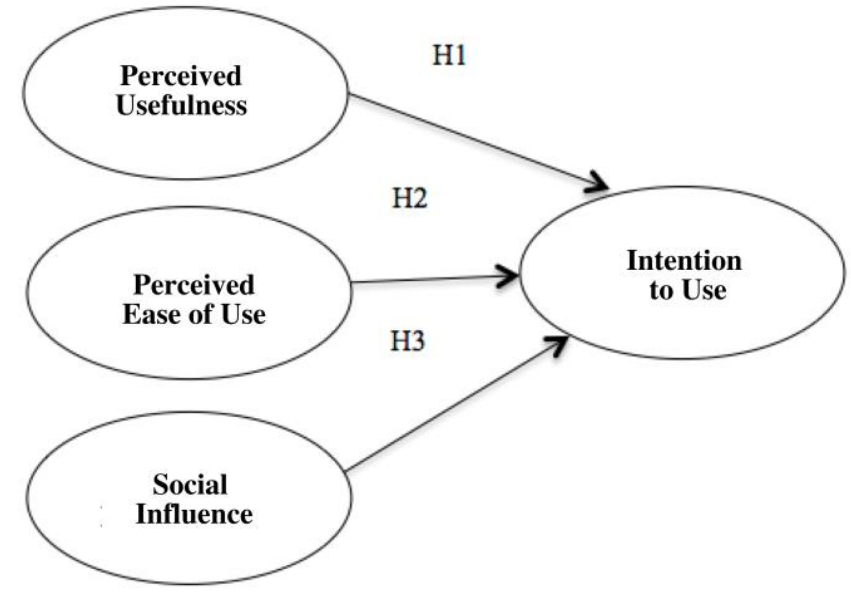

Research Model, 2020

\section{RESULTS AND DISCUSSION}

\subsection{Respondent Characteristics}

Based on the data collection results, $86(62.7 \%)$ of the total respondents were female, and the remaining 51 $(37.3 \%)$ were male. The respondents' age range was between 17 and 30 years old, all coming from Kota Karawang. The respondents had monthly allowance of Rp.50,000- Rp500,000, with the highest was 45 people $(32.8 \%)$ of the total respondents

\subsection{Validity Test Result}

Validity test to test the significance was conducted by comparing the value of rarithmetic with rtable for degree of freedom $=\mathrm{n}-\mathrm{k}$, alpha 0,05 then value rtable $=$ 0,1678 . Table 1 . Shows that all rarithmetic value $\geq$ 0.1678 .

Table 1. The Output of Validity est SPSS

\begin{tabular}{|l|l|l|l|}
\hline Item Kusioner & $\mathbf{r}_{\text {arithmetic }}$ & Item Kuisioner & $\mathbf{r}_{\text {arithmetic }}$ \\
\hline PU1 & 0.756 & SI1 & 0.881 \\
PU2 & 0.874 & SI2 & 0.816 \\
PU3 & 0.873 & SI3 & 0.802 \\
PU4 & 0.882 & IU1 & 0.862 \\
PEOU1 & 0.848 & IU2 & 0.931 \\
PEOU2 & 0.849 & IU3 & 0.903 \\
PEOU3 & 0.852 & & \\
\hline
\end{tabular}

Information: PU = Perceived Usefulness variable; PEOU = Perceived Ease of Use variable; $\mathrm{SI}=$ Social Influence variable; $\mathrm{IU}=$ Intention to Use variable

Sources: Data procesing, 2020

The results of the SPSS output show that all rarithmetic values are $\geq 0.1678$, then all questionnaire items are considered valid.

\subsection{Reliability Test Result}

Decision making for the reliability test is as follows: Croncbach Alpha $<0.60=$ poor reliability, Croncbach 
Alpha $0.60-0.79=$ acceptable reliability, Croncbach Alpha 0.946 = good reliability. The Croncbach's Alpha SPSS Output Results is $>0.886$, then all data are considered to have good reliability figures.

\subsection{Classic Assumption Test}

1. Normality Test

Test results from the SPSS output Asymp value. Sig. (2-tailed) of $0.115>0.05$, then the data is declared normally distributed.

2. Multicollinearity, Heteroscedasticity Test Result

The tolerance of each independent variable is bigger than 0.1 , while the VIF value of each independent variable is Perceived Usefulness = 2,810 and Perceived Ease of Use $=2,505$ and Social Influence $=1,219$ which means all are smaller than 10 , then the data is free from multicollinearity. Whereas for the heteroscedasticity test, the Sig value of the independent variables is Perceived Usefulness = 0.743 and Perceived Ease of Use $=0.644$ and Social Influence $=0.146>$ from 0.05 , then it is declared that there is no heteroscedasticity.

\subsection{Hypothesis Test Result}

1. Multiple Correlation Analysis (R)

The correlation coefficient is as follows:

- $\quad-0.199=$ very low

- $\quad 0.20-0.399=$ low

- $\quad 0.40-0.599=$ moderate

- $\quad 0.60-0.799=$ strong

- $\quad 0.90-1000=$ very strong

The results of multiple correlation testing $(\mathrm{R})$ can be seen in Table 2. Based on Table 2, the $\mathrm{R}$ number is 0.731 , which shows that there is a strong relationship between perceived usefulness, perceived ease of use, social influence variables with Intention to use e-wallet.

Table 2. Multiple Correlation (R)

\begin{tabular}{|c|c|c|c|c|c|c|c|c|c|}
\hline \multicolumn{10}{|c|}{ Model Summary } \\
\hline \multirow[b]{2}{*}{ Model } & \multirow[b]{2}{*}{$\boldsymbol{R}$} & \multirow[b]{2}{*}{$\begin{array}{c}R \\
\text { Square }\end{array}$} & \multirow[b]{2}{*}{$\begin{array}{c}\text { Adjusted } \\
R \\
\text { Square }\end{array}$} & \multirow{2}{*}{$\begin{array}{c}\text { Std. } \\
\text { Error } \\
\text { of the } \\
\text { Estimat } \\
e\end{array}$} & \multicolumn{5}{|c|}{ Change Statistics } \\
\hline & & & & & $\begin{array}{c}\text { R } \\
\text { Square } \\
\text { Change }\end{array}$ & $\begin{array}{c}\text { F } \\
\text { Chang } \\
e\end{array} \mid$ & $d f 1$ & $d f 2$ & \begin{tabular}{|c|} 
Sig. \\
F \\
Cha \\
nge
\end{tabular} \\
\hline 1 & $.731^{\mathrm{a}}$ & .508 & .497 & $\begin{array}{l}1.8264 \\
0\end{array}$ & .534 & 50.512 & 3 & 132 & $\begin{array}{l}.00 \\
0\end{array}$ \\
\hline
\end{tabular}

Predictors: (Constant), Social influence, Perceived ease of use, Perceived usefulness

Sources: Data procesing, 2020

\subsection{Statistical F-Test}

The $\mathrm{F}$ test is known as the simultaneous test or the Model test or Anova test, which is a test to see how all the independent variables influence the dependent variable together or to test whether the regression model is significant or non-significant.

Based on the results shown on Table 3 of calculations using the SPSS program, the $\mathrm{F}$ test significance probability score is 0.000 . Because the significance value is $<0.05$, so there is an effect of perceived usefulness, perceived ease of use, and social influence on employee intention to use simultaneously. Perceived usefulness, perceived ease of use, and social influence have a total effect of 50.512 with a significance level of 0.000 .

Table 3. ANOVA

\begin{tabular}{|l|l|l|l|l|l|l|}
\hline \multicolumn{2}{|c|}{ Model } & \multicolumn{1}{c|}{$\begin{array}{c}\text { Sum of } \\
\text { Squares }\end{array}$} & df & $\begin{array}{c}\text { Mean } \\
\text { Square }\end{array}$ & F & Sig. \\
\hline \multirow{2}{*}{1} & Regression & 547.845 & 3 & 182.615 & 50.512 & $.000^{\mathrm{b}}$ \\
\cline { 2 - 8 } & Residual & 477.214 & 132 & 3.615 & & \\
\cline { 2 - 7 } & Total & 1025.059 & 135 & & & \\
\hline
\end{tabular}

Dependent Variable: INTENTION TO USE

Predictors: (Constant), Social influence, Perceived ease of use, Perceived usefulness

Sources: Data procesing, 2020

\subsection{Statistical t-Test}

The $t$ test is used to determine whether the independent variable partially affect the dependent variable. Table 4 show the result data analysis.

Table 4. Result Data Analysis

\begin{tabular}{|c|c|c|c|c|c|}
\hline \multicolumn{6}{|c|}{ Coefficients $^{\mathrm{a}}$} \\
\hline \multirow[b]{2}{*}{ Model } & \multicolumn{2}{|c|}{$\begin{array}{c}\text { Unstandardized } \\
\text { Coefficients }\end{array}$} & \multirow{2}{*}{\begin{tabular}{|c|}
$\begin{array}{c}\text { Standardized } \\
\text { Coefficients }\end{array}$ \\
Beta \\
\end{tabular}} & \multirow[b]{2}{*}{$t$} & \multirow[b]{2}{*}{ Sig. } \\
\hline & $B$ & Std. Error & & & \\
\hline \begin{tabular}{|l|l|}
1 & (Constanta)
\end{tabular} & -.522 & 1.043 & & -.500 & .618 \\
\hline $\begin{array}{l}\text { Perceived } \\
\text { Usefulness }\end{array}$ & .275 & .085 & 293 & 3.233 & .002 \\
\hline $\begin{array}{l}\text { Perceived Ease } \\
\text { of Use }\end{array}$ & .546 & .105 & .438 & 5.193 & .000 \\
\hline \begin{tabular}{|l} 
Social \\
Influence
\end{tabular} & .072 & .053 & .092 & 1.356 & .178 \\
\hline
\end{tabular}

Dependent Variable: Intention to use

Sources: Data processing, 2020

From the table 4 above, the following (1) is acquired:

$Y=-522+0.275 X 1+0.546 X 2+0.72 X 3$

Based on Table 4, the significance value of perceived usefulness is 0.002 <from 0.05 , and it can be seen that perceived usefulness has a partial effect on intention to use e-wallet. The regression analysis test results obtained a regression coefficient of 0.275 , which means that every perceived usefulness change will also affect an increase in intention to use e-wallet by 0.275 , assuming other variables are constant. Perceived usefulness influences by 3,233 . The perceived ease of use significance value is $0.000<$ from 0.05 , and it can be seen that perceived ease 
of use has a partial effect on intention to use e-wallets. The regression analysis test results obtained a regression coefficient of 0.546 , which means that every change in perceived ease of use will also increase the intention to use e-wallet by 0.546 , assuming other variables are constant. Perceived usefulness influences by 5,193 . This result indicates that the intention of STMIK ROSMA information system study program students to use ewallet is influenced by the ease, need, and use of transactions that are considered more efficient. Variable social influence significance value is $0.178>$ from 0.05 , which shows that there is no significant effect on the intention to use. This can be caused by the respondents being examined are millennials who are freer and less influenced by others about their intentions or desires for e-wallet.

\subsection{Determination Coefficient}

Determination coefficient is denoted by $\mathrm{R}$ square. This value determines the variation in the value of the dependent variable that can be accepted or results from a linear relationship with the independent variable, other than that are explained by other variables. The coefficient of determination ( $\mathrm{R}$ square) ranges from 0 to one $(0 \leq \mathrm{R} 2 \leq 1)$.

Based on Table 5, the adjusted r-square value obtained is 0.508 or $50.8 \%$ showing the contribution of the variable perceived usefulness, perceived ease of use, and social influence in explaining its effect on the dependent variable use intention is $50.8 \%$ while the rest $(49.2 \%)$ is influenced by other variables outside this study.

Table 5. Hypothesis Determination Coefficient.

\begin{tabular}{|l|c|l|l|c|}
\hline \multicolumn{5}{|c|}{ Model Summary } \\
\hline Model & $\boldsymbol{R}$ & $\boldsymbol{R}$ Square & Adjusted R Square & $\begin{array}{c}\text { Std. Error of the } \\
\text { Estimate }\end{array}$ \\
\hline 1 & $713^{\mathrm{a}}$ & .508 & .497 & 1.82640 \\
\hline
\end{tabular}

\section{CONCLUSION}

This study concludes that there was a significant variable effect of perceived usefulness, perceived ease of use on an intention to use e-wallet. While the social influence variable had no significant effect. This finding shows the same results as the research conducted by [13] that obtained empirical results that perceived ease of use and perceived usefulness impacted the intention to use social networks. In addition, a research result obtained by [14] showed that perceived ease of use, usefulness, perceived risk, and attitude had a significant effect on the intention to use e-wallet. Reference [15] showed that latent variables, planned behavior, and technology acceptance model (TAM) use had a significant impact on encouraging behavioral intentions to use Islamic FinTech, highlighting matters that intersect with trust users embrace.

From the results of this study, it is suggested to make the application more convenient and easier to use and be consistent in service. However, the use of public figures to increase user intentions is considered not necessary because millennials in this study were not influenced by the figures they idolize.

\section{ACKNOWLEDGMENTS}

We would like to express our deepest gratitude to all lectures in the study program at School of Post Graduate Studies in Universitas Pendidikan Indonesia, who have facilitated and helped with the research from the beginning till its completion

\section{REFERENCES}

[1] W. C. Chen, C. W. Chen, and W. K. Chen, "Drivers of mobile payment acceptance in China: An empirical investigation," Inf., vol. 10, no. 12, pp. 1-20, 2019.

[2] J. C. Mowen and M. C. Minor, "Consumer Behavior: A Framework," USA Prentice Hall, 2001.

[3] Y. D. Handarkho and Y. Harjoseputro, "Intention to adopt mobile payment in physical stores: Individual switching behavior perspective based on PushPull-Mooring (PPM) theory," J. Enterp. Inf. Manag., vol. 33, no. 2, pp. 285-308, 2019.

[4] M. Nabila, B. Purwandari, B. A. A. Nazief, D. A. Chalid, S. S. Wibowo, and I. Solichah, "Financial technology acceptance factors of electronic wallet and digital cash in Indonesia," in 2018 International Conference on Information Technology Systems and Innovation, ICITSI 2018 - Proceedings, 2018.

[5] R. Odoom and J. P. Kosiba, "Mobile money usage and continuance intention among micro enterprises in an emerging market - the mediating role of agent credibility,” J. Syst. Inf. Technol., vol. 22, no. 4, pp. 97-117, 2020.

[6] C. Phonthanukitithaworn, C. Sellitto, and M. W. L. Fong, "An investigation of mobile payment (mpayment) services in Thailand," Asia-Pacific J. Bus. Adm., 2016.

[7] F. D. Davis, "Perceived usefulness, perceived ease of use, and user acceptance of information technology," MIS Q. Manag. Inf. Syst., vol. 13, no. 3, pp. 319-339, 1989.

[8] M. Meyliana, E. Fernando, and S. Surjandy, "The influence of perceived risk and trust in adoption of fintech services in Indonesia," CommIT (Communication Inf. Technol. J., vol. 13, no. 1, p. 31, 2019.

[9] P. Su, L. Wang, and J. Yan, “How users' Internet experience affects the adoption of mobile payment: a mediation model," Technol. Anal. Strateg. Manag., vol. 30, no. 2, pp. 186-197, 2018. 
[10] V. Venkatesh, M. G. Morris, G. B. Davis, and F. D. Davis, "User acceptance of information technology," MIS Q., 2003.

[11] I. R. de Luna, F. Liébana-Cabanillas, J. SánchezFernández, and F. Muñoz-Leiva, "Mobile payment is not all the same: The adoption of mobile payment systems depending on the technology applied," Technol. Forecast. Soc. Change, vol. 146, no. October 2017, pp. 931-944, 2019.

[12] N. Sobti, "Impact of demonetization on diffusion of mobile payment service in India: Antecedents of behavioral intention and adoption using extended UTAUT model," J. Adv. Manag. Res., vol. 16, no. 4, pp. 472-497, 2019.
[13] J. C. M. Rodrigues Pinho and A. M. Soares, "Examining the technology acceptance model in the adoption of social networks," J. Res. Interact. Mark., vol. 5, pp. 116-129, 2011.

[14] N. Singh, N. Sinha, and F. J. Liébana-Cabanillas, "Determining factors in the adoption and recommendation of mobile wallet services in India: Analysis of the effect of innovativeness, stress to use and social influence," Int. J. Inf. Manage., vol. 50, no. May 2019, pp. 191-205, 2020.

[15] Darmansyah, B. A. Fianto, A. Hendratmi, and P. F. Aziz, "Factors determining behavioral intentions to use Islamic financial technology: Three competing models," J. Islam. Mark., no. August 2019, 2020. 